\begin{tabular}{c} 
Volume and Issues Obtainable at Center for Sustainability Research and Consultancy \\
Journal of Accounting and Finance in Emerging Economies \\
ISSN: 2519-0318 ISSN (E) 2518-8488 \\
Volume 6: Issue 1 March 2020 \\
CSRᄃ \\
Journal homepage: www.publishing.globalcsrc.org/jafee \\
\hline
\end{tabular}

\title{
The Role of Rater Motivation and Training in Effective Performance Appraisal System in Public Sector Universities of Khyber Pakhtunkhwa, Pakistan
}

\author{
${ }^{1}$ Muhammad Asad khan, ${ }^{2}$ Altaf Hussain, ${ }^{3}$ Mohammad Hanif khan \\ ${ }^{1}$ PhD Scholar, Universiti Tun Hussein Onn (UTHM) Malaysia: asadkhan818@yahoo.com \\ ${ }^{2}$ Assistant Professor, Department of Commerce and Management Sciences, University of Malakand, Khyber \\ Pakhtunkhwa, Pakistan: altafhussain@uom.edu.pk \\ ${ }^{3}$ Lecturer, Department of Tourism and Hotel Management, University of Malakand, Khyber Pakhtunkhwa, \\ Pakistan: hanifyousafzai@uom.edu.pk
}

\begin{tabular}{l} 
ARTICLE DETAILS \\
\hline History \\
Revised format: February 2020 \\
Available Online: March 2020 \\
\\
Keywords \\
Rater Training, Rater Motivation, \\
Performance Appraisal, Higher \\
Education Institutions
\end{tabular}

JEL Classification:

$J 31$,

ABSTRACT

Performance appraisal is considered to be the most significant element of performance management but often the former involves controversial practices, among other variables influenced by accuracy and effectiveness. However, it is generally understood that performance appraisal system commonly result into positive organizational outcomes, yet the accuracy of the measuring tools is still an arguable issue with more criticisms. The ongoing matters are measured and tested as a case study approach by paying attention on higher education institutions. Since higher education is progressively playing a vital role in economic competitiveness of a country. Aiming to examine the effect of rater motivation and rater training on performance appraisal process in public sector universities of Khyber Pakhtunkhwa, Pakistan and recognized as a critical contribution to organizational and people's performance. Thus, this study finds the effects and consequences of rater motivation and rater training on performance appraisal system. This study is survey based, 300 questionnaires in total were distributed among the faculty of public sector universities of Khyber Pakhtunkhwa (KP), Pakistan. Out of which 160 were received back recording response rate of 53\%. Findings of this study indicate that there was positive and significant relationship between rater motivation and performance appraisal and also between rater training and performance appraisal in public sector universities of Khyber Pakhtunkhwa, Pakistan. The current study offers researchers with the opportunity to search performance appraisal from a new perspective which has never been explored before in a developing country like Pakistan.

(C) 2020 The authors, under a Creative Commons Attribution-Non Commercial 4.0

Corresponding author's email address: asadkhan818@yahoo.com

Recommended citation: Khan, M. A., Hussain, A. \& khan, M. H., (2020). The The Role of Rater Motivation and Training in Effective Performance Appraisal System in Public Sector Universities of Khyber Pakhtunkhwa, Pakistan. Journal of Accounting and Finance in Emerging Economies, 6 (1), 155-166

DOI: $10.26710 /$ jafee.v6i1.1064 


\section{Introduction}

Universities as institutions can perform a prominent role in economic growth, social and human development of a country; many governments are inclined to expand the sectors capacity and quality for new frontiers (Saba \& Nsubuga-Kyobe, 2014), thus high quality and quantity in the higher education sector cannot be accomplished without consistent evaluation and improvement of academic staff performance assessment (Linna et al., 2012). Universities as institutions are used so as to highlight the performance appraisal accuracy regarding rater motivation and training based on public sector universities from Pakistan (Saba \& Nsubuga-Kyobe, 2014). The significance of performance appraisal for certain organizational acitivites like motivation, training, recruitment and selection, compensation has been widely discussed (Zhang, 2012). Accuracy in performance assesment has been a leading concern for the last 50 years (Lee, 1985). Efforts commonly have been carried out to rectify the rater errors, as these rating errors are mostly caused due to the lack of training and motivation of rater. Such training and motivation of rater enhance the rating accuracy in performance appraisal (Lee, 1985). Researchers and practitioners have made and implemented various changes to employees assesment criteria, rating instruments and techniques used for performance appraisal. All these changes were made in an effort to make the process fair and accurate (Kisang \& Kirang, 2016). Though, some researchers have emhasized on the training of raters and rater motivation in insturments and methods of performance appraisal (Park, 2017). Managers/raters have a key impact on organizational outcomes and performance at all levels of an organization (Powell \& Yalcin, 2010). Since managerial education regarding knowledge, skills and abilities is critical for today's success of organizations (Kutshera \& Byrd, 2005), rater/managerial training and development has declared as a vital business issue for organizations. Powell \& Yalcin, (2010) argued the vital role of training and proper motivation in the improvemnt and development of effective managers and raters in both public and private organizations. Performance appraisal can be viewed as a significant technique using supervisors to motivate raters, increase employee performance and distribute rewards among employees which affect both individual and organizational performance accordingly (Buller \& McEvoy, 2012). As raters has a significant role in the process of performance appraisal, still stimulating accuracy in the raters of different organizations and institutions has been an important problerm (Lahuis \& Avis, 2007). Recent studies, have pointed towards the effects rater motivation has on the accuracy of performance appraisal (Wang et al., 2010). Nevertheless, due to superviory nature of performance appraisals, work design aspects, that is, rater training and motivation has been less explored area in the literature (Wang et al., 2010). It is evident from research that organizational experience that effective performance appraisal system need two components in place i.e. developed rating methods and rater training (Kumar, 2005). According to Imtiaz Ahmad et al. ( 2013) untrained rater and less motivated rater are among the top hindering factors of effective performance systmes in public secor universits of pakistan which needs to be addressed.

\section{Literature Review}

\subsection{Performance Appraisal}

One of the important human resource function and practices is performance appraisal. If used efficiently, it attempts to develop competitiveness, innovation, employee improvement, productivity as well as motivation and performance enhancement (Murphy \& Cleveland, 1995; Saba \& Nsubuga-Kyobe, 2014). As the role of performance appraisal is crucial in the success of organizaiton, effectiveness of performance appraisal system is indispensible in order to evaluate employee's performance fairly and accurately (Saba \& Nsubuga-Kyobe, 2014). In the performance appraisal context, work performance is related with accuracy in performance appraisal. All the dimesnions related to job has effect on rater motivation and accuracy of performance appraisals (Park, 2017). First, the appraisers need variety of skills and such skills not only make the job meaningful but also results in improved rating accuracy (Rosso, Dekas \& Wrzesniewski, 2010). Second important thing in performance appraisal is the task identification by the rater which has an observable outcome in the performance rating (Rosso, Dekas \& Wrzesniewski, 2010). Third is the task importance in performance appraisal which has a reflection in performance ratings of employees and also affect the employee improvement and personnel decisions. 
Furthermore, the more autonomy and responsibility the rater feels in rating the employees ${ }^{6}$ perfomance, the more efforts and energy rater put to make the appraisal system better (Rosso, Dekas \& Wrzesniewski, 2010; Park, 2017). Lastly, getting feedback directly from thier subordinates or employees, make the raters more knowledgeable about thier tasks results which in turn ehance their accuracy by developing their work performance (Mero, Guidice \& Brownlee, 2007), subject to the institutional settings or rating systems.

In the ongoing literature, the existing limitations of rater motivation and rater training in a relationship with performance appraisal are also highlighted to reach the actual obstacles that can harm performance appraisal system's effeciveness of public sector univeristies particulary in Pakistan. Performance appraial system is criticized due to the biases which occur due to lack of knowledge, skills and abiliites in raters (Bekele et al., 2014). For performance appraisal to be worthwhile, regardless of their particular purpose it should be accurate as possible regarding performance ratings. It has been noted that many problems of evaluation ratings are the outcomes of adaptive and goal driven behavior of rater and such probmes in true evaluation donot occur due to the inabliity of raters (Tziner et al., 2005). These problems cannot be termed as rating errors and thereby cannot be solved by using different rating scales but only be rectified through rater motivation and rater training (Tziner, et al., 2005). Moreover, performance appraisal is contaminated with non-performance factors like impression management and rater motivation (Spence \& Keeping, 2011; Nayyar \& Raja, 2012). So far less empirical research has been carried out for examining the effects of rater's motivation on performance appraisal in context of higher education sector in Pakistan (Saba \& Nsubuga-Kyobe, 2014). Due to inappropriate training of rater most of the performance appraisal systems subject to weakness (Bohlander et al., 2001). Because they lack precise standards of assessment for subordinates performance and also lack necessary observational and feedback skills. The main hindering factors for effective performance appraisal system in public sector universities of Pakistan are untrained rater and low level of rater motivation which needs to be addressed (Imtiaz Ahmad et al., 2013). In respond of feedback, raters may sometimes distort ratings to justify their rating decisions.

The first gap about performance appraisal which is contaminated with non-performance factors like impression management and rater motivation (Spence \& Keeping, 2011; Nayyar \& Raja, 2012). So far very less empirical research has been conducted to examine the effects of rater's motivation on performance appraisal context in higher education sector of Pakistan (Saba \& Nsubuga-Kyobe, 2014). So such gap present in the research is of crucial importance. A study reveals that few organizations carry out rigorous and skill based training of their raters (Grote, 1996). In public sector universities of Pakistan, very limited research has been carried out so far, on rater training to make performance appraisal able to be effective in terms of performance ratings and this gap needs to be addressed (Imtiaz Ahmad et al., 2013).

\subsection{Rater Motivation}

The thrilling development of studying the concept of rater motivation provided further opportunity to search performance appraisal (Saba \& Nsubuga-Kyobe, 2014), from a new dimension. The "concept of rating motivation" may be confusing as it illustrates instances in which raters perform around with i.e. expand, shrink or consolidate ratings (Tziner, Murphy \& Cleveland, 2001). The other instances that come under the "concept of rating motivation" includes rater's lack of motivation for accurate rating (Bank \& Murphy, 1985), rater's motivation to assign inaccurate rating (Cleveland \& Murphy, 1992) and rater's having no interest at all in fair ratings (Harris, 1994).

\subsection{Rater Motivation in Performance Appraisal Context in Pakistan}

Organizational effectiveness is dependent both on organizational as well as individual performance (Gong, Law, Chang, \& Xin, 2009). Notwithstanding, majority public sector organizations in Pakistan including universities are using performance appraisal system namely Annual Confidential Report (ACR) 
to evaluate employee's performance annually by his immediate supervisor (Rehman, 2012). Since its commencement, the system has been corrected many times to clarify some technical problems by higher education commission Pakistan (Rasheed et al., 2011), though some development has been done in last decade but the existing performance appraisal system is still far away from success in practical operation and world level standards. The shortcomings observed in such reports challenge both the success and fairness of the performance appraisal system by yielding subjective ratings of employee job performance (Saba \& Nsubuga-Kyobe, 2014). As identified by Murphy, (2008) regardless its popularity and importance in various organizations, the link connecting actual performance with subjective ratings of job performance is not strong comparatively. Moreover, non-performance factors like impression management and rater motivation has also contaminated performance appraisal of employees (Spence \& Keeping, 2011; Nayyar \& Raja, 2012). Giles and Mossholder (1990) postulated that employees' satisfaction with performance appraisal session is ensured when feedback is more specific, timely and correct led by rater motivation. It is assumed, hence, that if rater motivation is higher, employee satisfaction with performance appraisal process will be higher and vice versa.

\subsection{Determinants of Rater Motivation}

Determinants of rater motivation i.e. perceived rewards, perceived negative consequences and impression management are important one among others determinants (Cleveland \& Murphy, 1992). It is also supposed that both situational (accountability) and personal (mood) variables influence these determinants. According to Cleveland and Murphy (1992) extensive discussion has been made on these three determinants of rater motivation in context with performance appraisal. Another scholar also highlights these determinants as the predictor of performance ratings (Harris, 1994).

\subsection{Reward}

In performance appraisal, raters are subject to the possibility of getting rewards in the form of raises and promotions. Most of the public sector universities used performance appraisal for promotion purposes (Anjum, Yasmeen \& Khan, 2011) and this is considered as one of the major issue. Fletcher, (2001) is of the view that organizations need to recognize and develop employee competence regarding their improvement in performance as well as to allocate rewards to them. According to Murphy \& Cleveland (1991) in practice, extrinsic rewards has been used frequently in engaging performance appraisal activities, but it has worthwhile for making accurate ratings regarding rater motivation.

\subsection{Negative Consequences}

Negative consequences are termed as second determinant of rater motivation in the context of performance appraisal. Negative consequences related with performance appraisal system are many in numbers (Alonso \& Lewis, 2001), but damage to subordinate supervisor relationship, lowering morale of employees, subordinate criticism on raters, supervisor criticism on raters and intervention with other tasks are worthy to mention (Murphy \& Cleveland, 1991). Mangers show uneasiness when accurate performance ratings are made or negative performance feedback results in damage of relationship with employees (Longenecker et al., 1987). Employees also raise voices concerns about censured employee ratings and feedback particularly if such feedback and ratings are not positive and beyond the employees' expectation (Murphy \& Cleveland, 1991). Such problems related with performance appraisal prevails everywhere but it is considered an unexplored phenomenon engrained in performance appraisal system of public sector organizations of Pakistan (Khan, 2010).

Performance appraisal in public sector universities' is only used at low level for communication and having little feedback from rater's to subordinates and such relationship is very scarce in such a closed appraisal system (Khan, 2010). Findings of performance appraisal systems are kept secret from employees. The management shows unwillingness for communicating negative information so as to avoid direct conflict with employees and a face saving is done as well (Khan, 2010). Such confidentiality of 
information from employees leads to mistrust and culture of secrecy and distances in the relationship of rater and subordinate.

\subsection{Impression Management Concerns}

Villanova and Bernardin (1989, p.299) defined impression management as "any behaviour that alters or maintains a person's image in the eyes of another and that has as its purpose the attainment of some valued goal". Impression management activities are more in the workplace. According to Nayyar and Raja (2012), motives for both politics and impression management actions in organizational environment in higher educational sector in Pakistan may involve inflating employee's ratings to avoid conflict with employees and to encourage anxious employees out of one's department. Researchers have also identified that rater also involve in impression management activities (Villanova \& Bernardin, 1989). While, Harris (1994) argued that accountability to employees would result to inflated ratings because of rater's concerns that negative ratings will decrease employee's motivation and hurt rater's relationship with employees. Latest study has found that accountability may result into more fair and accurate ratings as long as rater's or employee's opinion is not known to the rater (Graham et al., 2012). According to Harris (1994), task outcome dependence should enhance rater motivation i.e. the greater the degree to which rater's outcome is related to the employee's work (task dependence), the more likely the rater will give fair ratings and accurate feedback.

\subsection{Rater Training}

Performance appraisal needs a trained rater to accurately evaluate the performance of employees. While assigning ratings, rater must be reasonable, accurate and objective (Kumar, 2005). Due to inappropriate training of rater most of the performance appraisal systems subject to weakness (Bohlander et al., 2001). Because these raters lack precise standards for assessing performance of subordinates and also lack necessary observational and feedback skills. A study reveals that very less organization provide rigorous and skill based trainings to their raters (Grote, 1996). Previous literature shows that training of rater can decrease rater effects and rater errors (Kumar, 2005). According to Duncan (1983), rater training is of special importance because it helps them to understand and use performance appraisal system in such a way which highlight and enhance its positive aspects. Training makes the appraisers accurate and reliable raters and help decrease common errors like halo and leniency. Such errors can also be removed by attending workshops and training sessions where they practice rating behaviors (De Cenzo dan Robbins, 1996). Without training, raters may harm the overall effectiveness of performance appraisal (Armstrong, 1988). Performance appraisal system loses its efficacy and excellence if the raters or managers lack the knowledge of using it for positive effects.

Training can be used for many purposes such as setting objectives, maintaining and keeping accurate records and communicating all aspects of performance appraisal (Boice \& Kleiner, 1997). The main hindering factors for effective performance appraisal system in public sector universities of Pakistan are untrained rater and low level of rater motivation which needs to be addressed (Ahmad et al., 2013).

\subsection{Relationship of Rater Motivation with Performance Appraisal}

Performance appraisal system is used in almost every organization but common one is supervisory performance ratings (Murphy, 2008) for assessment of employee performance. It is a certain fact that performance appraisal has got its importance and popularity around the globe but actual performance is weakly related with subjective ratings of job performance (Murphy, 2008). Performance appraisal has been contaminated with non-performance factors such as impression management, negative consequences so the performance rating is affected badly (Djurdjevic, 2013). The lack of distinguished advancement in developing performance appraisal accuracy is largely due to the fact that raters are less keen or less motivated to provide correct performance ratings. Various researchers pointed out that attention may be given to rater motivation in performance appraisal for the last three decades (Mohrman \& Lawler, 1983). 
The focus has now been shifted to determine the impact of rater motivation on accuracy of performance appraisal. It is showed empirically by Wong and Kwong (2010) that raters have more interest in accomplishment of personal goals instead of provision of fair and accurate performance ratings. Various scholars have been argued that performance appraisal has got influence on rater goals and rating accuracy (Harris, 1994).

\subsection{Relationship of Rater Training with Performance Appraisal System}

Rater training is considered to be the most significant method that enables effective performance appraisal system (Anjum et al., 2011). The researcher further explains it, this is one of the critical issue related to the existing performance appraisal system. According to Kumar (2005) performance appraisal system has a relationship with rater training regarding performance ratings and rating accuracy. The basic need of performance appraisal is that rater should get objective results of employee job performance and applied that rating for the aim of improving performance (Kumar, 2005). Untrained raters create rating errors during measuring employee job performance and in turn which reduces the utility of performance appraisal system. A research done by Ahmad et al. (2013) and his results reveal that hindering factors of performance appraisal system in Pakistani universities are rater training and low level of rater motivation. From the studies of previous scholars (Longenecker, 1997; Kumar, 2005) it has been concluded that rater training is positively related with performance appraisal system.

\section{Research Framework}

The research framework for this study is based on the results of the previous studies which shows postive relationship for both rater motivation and rater training with perfornance appraisal (Decotiis \& Petit, 1978; Longenecker, 1997; Kumar, 2005). In other words, if the rater is motivated and trained, the performance appraisal is assessed accurately and vice versa. The framework of this study is based on social exchange theory which elaborates that if the rater is motivated and has the required training for appraising the employees, performance appraisal is assessed accurately. Based on the findings of previous studies it is proposed that rater motivation and rater training is postively related with performance appraisal of employees in public sector universites of Pakistan. (Refer Fig.1)

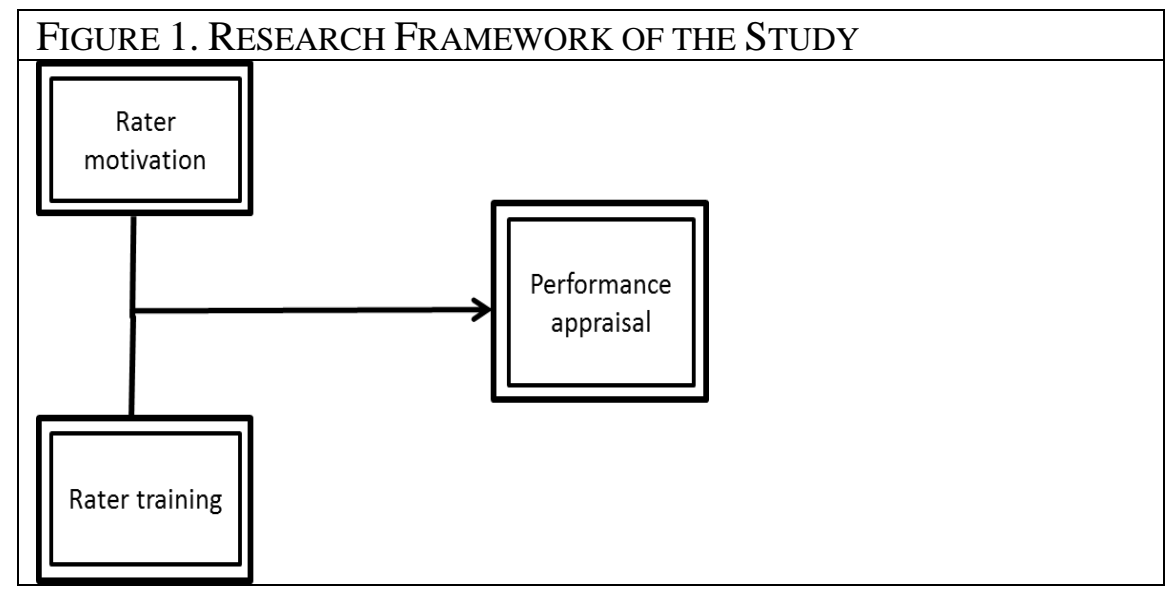

\section{Research Methodology}

This study used survey based questionnaire to collect data from respondents. Simple random sampling (SRS) technique was utilized as sampling frame in the study. A total of 300 questrionnaires were sent to the faculty members of six public sector univerities of KP, Pakistan. Out of these 300, 160 filled questionaires were recieved back recording a response rate of $53 \%$. 


\subsection{Measures}

The constructs applied in this research were:

Performance appraisal system scale: the scale was used to measure performance appraisal. This scale was taken from Pearce and Porter (1986). It is a five-point likert scale ranging from "strongly agree" (5) to "strongly disagree" (1). The performance appraisal scale included of (5) items having alpha coefficient reliability of 0.93 .

Rater motivation: the scale used to evaluate rater motivation was adopted and taken from the study of Park (2013). It is a five-point likert scale ranging from "strongly agree" (5) to "strongly disagree" (1). This scale has been tested earlier with alpha coefficient of 0.83 .

Rater training: the scale used to assess rater training was adopted and adapted from the study of Elverfeldt (2005). It is a five-point likert scale ranging from "strongly agree" (5) to "strongly disagree" (1). This scale is found reliable with alpha coefficient of 0.73 .

\subsection{Analysis of Data}

Laatest version of SPSS was used to analyze the data of the study. Both correlation and regression anlaysis was carrried out. The results have been elaborated with the help of tables. First performance appraisal is analyzed with the help of Pearson correlation with rater motivation and rater training. The coefficient of correlation among constructs is given in detail in the (Table 1).

Correlation analysis was carried out in connection to operationalize relationships among variables. The correlation coefficient between rater motivation and performance appraisal is 0.634 , representing that both variables are strongly positivley correlated with each other

\section{Table 1:}

\begin{tabular}{|c|c|c|c|c|}
\hline \multicolumn{5}{|c|}{$\begin{array}{l}\text { TABLE1: CORRELATIONS OF RATER MOTIVATION, RATER TRAINING AND PERFORMANCE } \\
\text { APPRAISAL }\end{array}$} \\
\hline & & Rater motivation & Rater training & $\begin{array}{l}\text { Performance } \\
\text { appraisal }\end{array}$ \\
\hline \multirow[t]{3}{*}{$\begin{array}{l}\text { Rater } \\
\text { motivation }\end{array}$} & $\begin{array}{l}\text { Pearson } \\
\text { Correlation }\end{array}$ & 1 & $.861 * *$ & $.634 * *$ \\
\hline & Sig. (2-tailed) & & .000 & .000 \\
\hline & $\mathrm{N}$ & 306 & 306 & 306 \\
\hline \multirow[t]{3}{*}{ Rater training } & $\begin{array}{l}\text { Pearson } \\
\text { Correlation }\end{array}$ & $.861 * *$ & 1 & $.650 * *$ \\
\hline & Sig. (2-tailed) & .000 & & .000 \\
\hline & $\mathrm{N}$ & 306 & 306 & 306 \\
\hline \multirow[t]{3}{*}{$\begin{array}{l}\text { Performance } \\
\text { appraisal }\end{array}$} & $\begin{array}{l}\text { Pearson } \\
\text { Correlation }\end{array}$ & $.634 * *$ & $.650 * *$ & 1 \\
\hline & Sig. (2-tailed) & .000 & .000 & \\
\hline & $\mathrm{N}$ & 306 & 306 & 306 \\
\hline
\end{tabular}

While the correlation coefficient between rater training and rater motivation is 0.861 showing that both the variables are strongly postively correlated with each other. While the correlation coefficient between rater training and performance appraisal is 0.65 , also showing that both the variables are strongly positively correlated. 
The value of coefficient determination (R2) is found as 0.443 , which reveals that change of $44.3 \%$ in the dependent variable i.e. performance appraisal is occured due to the independent variables i.e. rater motivation and rater training. The change is not only caused by independent variables but some other factors also contribute in the improvement of performance appraisal. Overall the model of the study is significant (Refer Table 2).

\begin{tabular}{|l|l|l|l|l|}
\hline \multicolumn{4}{|l|}{ TABLE2: MOdEL SUMMARY OF RATER MOTIVATION AND RATER TRAINING } \\
\hline Model & R & R Square & Adjusted R Square & Std. Error of the Estimate \\
\hline 1 & $.685 \mathrm{a}$ & .443 & .492 & .63428 \\
\hline
\end{tabular}

The F statistic 116.645 indicates strong relationship between variables, through the significant level is at its optimum having value 0.000 (Refer Table 3), which leads to accept the hypotheses

TABle3: ANOVA Between Rater Motivation AND PERFormance APPRAisAl

\begin{tabular}{|l|l|l|l|l|l|}
\hline \multirow{2}{*}{ Model } & & & & & \\
& Sum of Squares & Df & Mean Square & F & Sig. \\
\hline Regression & 92.208 & 2 & 45.604 & 116.645 & $.000 \mathrm{~b}$ \\
\hline Residual & 121.107 & 304 & .404 & & \\
\hline Total & 214.315 & 305 & & & \\
\hline
\end{tabular}

a. Dependent Variable: performance appraisal.

b. Predictors: (Constant), rater motivation, rater training.

The beta $(\beta)$ value $=.459$ for rater motivation which identified that one unit increase in independent variable (rater motivation) will increase the dependent variable (performance appraisal) up to 0.4 units as per table 4 . While the beta $(\beta)$ value for other dependent variable (performance appraisal) is .283 which shows that one unit increase in rater motivation will enhance the dependent variable (performance appraisal) up to 0.2 units according to table 4 .

\begin{tabular}{|c|c|c|c|c|c|}
\hline \multirow[b]{2}{*}{ Model } & \multicolumn{2}{|c|}{$\begin{array}{l}\text { Unstandardized } \\
\text { Coefficients }\end{array}$} & \multirow{2}{*}{\begin{tabular}{|l} 
Standardized Coefficients \\
Beta \\
\end{tabular}} & \multirow[b]{2}{*}{$\mathrm{T}$} & \multirow[b]{2}{*}{ Sig. } \\
\hline & $\mathrm{B}$ & Std. Error & & & \\
\hline (Constant) & .409 & .283 & & 2.061 & .040 \\
\hline Rater motivation & .532 & .087 & .459 & 6.995 & .000 \\
\hline $\begin{array}{l}\text { Performance } \\
\text { appraisal }\end{array}$ & .257 & .086 & .283 & 4.181 & .002 \\
\hline
\end{tabular}

The findings of this study reveal that if rater is highly motivated, trained and accurate in assigning performance ratings to their subordinates then employees will perceive performance appraisal is fair enough and subsequently will be motivated and satisfied and in turn will put more efforts to improve their performance. So, such enhancement in employee performance will lead to organizational performance and better productivity. 
To analyze the results of this study, these findings are in accordance with the earlier results of various researchers (Harris, 1994; Longenecker, 1997; Kumar, 2005; Decotiis \& Petit, 1978) opined that rater motivation and rater training has a positive and significant relationship with performance appraisal. These results also confirmed that the findings of previous researchers (Kumar, 2005; Decotiis \& Petit, 1978) that rater motivation and rater training has a positive and significant relationship with performance appraisal. The research on motivation theory further elaborates the limitations of cognitive process research which existed for over past twetny years (Roch et al., 2011). The critiques have highlighted the problems including rating inaccuracy which is an involuntary rating errors connected with cognitive limitations (Wang et al., 2010). It is further corroborated that raters need to be motivted and trained in order to conduct fair and accurate performance appraisal. Thus if the knowledge and skills of raters are devloped for assessment of performance, such development of knowledge and skills of raters leads to enhanced rating accuracy of performance appraisal. Such trainings seek to improve performance appraisal accuracy by minimizing raters errors (Decotiis \& Petit, 1978). The trainings of raters should be proper and accurate rating instruments further increase the capability of raters to be fairer while assigning perfornance ratings (Decotiis \& Petit, 1978).

\section{Conclusions and Recommendations}

Various scholars have recently proposed that rater motivation and rater training are important factors in understanding performance appraisal problems. Higher education sector of pakistan are faced with many challanges and problems, one serious problem is the lack of proper performance appraisal sytmem. Government has struggled to bring improvement in the higher education sector but still these efforts towards improvement of performance appraisal system has not lead to the expected results. Research for last fifteen years (Ahmad, 2010; Andrabi, Das, \& Khwaja, 2002) has documented that inspite that different innovations and sufficient financial aid by both foreign and local donors to the national education system has not added to the desired quality of higher eduacation system of pakistan particularly in univerities (National Education Policy, 1998- 2010). It seems like higer education system of Pakistan is seriously dwindling and requires proper attention and transformation. Several factors contribute toward this decline of quality, one of which is lack of fair and transperent performance appraisal system in universities of Pakistan. Another factor could be the proper implementation of performance appraisal system, though steps have been taken toward improvement of its implementaton in KP, public sector universities of Pakiatan. Despite the steps taken for its improvement in the last decade, appraisal system still needs proper practical operation. In ordr to overcome such problems and issues, the performance appraisal system need to be aligned with the current practices and expertise of human resource. The connection of performance appraisal system with the socical factors like rater motivatio and rater training needs to be understood.

\section{Limitations /Future Research}

The limitations of this study was that it has been conducted only in one part of the Pakistan i.e. Khyber Pakhtunkhwa. The second limitation is confinement of this study to only public sector universities of Pakistan. The research design of this study is quantitative based and future study can included qualitative design using other variables i.e. feedback, employee participation and employee satisfaction. Future study can also include other regions of Pakistan for both public and private sector universities.

\section{References}

Anjum, A., Yasmeen, K., and Khan, B. (2011) Performance Appraisal Systems in Public Sector Universities of Pakistan, International Journal of Human Resource Studies, 1(1), 41- 51.

Ahmed, A., Hussain, I., Ahmed, S., \& Akbar, M. F. (2010). Performance appraisals impact on attitudinal outcomes and organisational performance. International Journal of Business and Management, 5(10), 62-68.

Alonso, P., \& Lewis, G. B. (2001). Public service motivation and job performance: Evidence from the federal sector. The American Review of Public Administration, 31(4), 363-380. 
Ayupp, K., \& Kong, W. (2010). The impact of task and outcome interdependence and self-efficacy on employees' work motivation: an analysis of the Malaysian retail industry. Asia Pacific Business Review, 16(1-2), 123142.

Armstrong, M. 1988. A handbook of personnel management practice. 3rd Ed. London: Kogan Page Ltd.

Ahmed, I., Sultana, I., Paul, S. K., \& Azeem, A. (2013). Employee performance evaluation: a fuzzy approach. International Journal of Productivity and Performance Management, 62(7), 718-734.

Anjum, A., Yasmeen, K., \& Khan, B. (2011). Performance appraisal systems in public sector Universities of Pakistan. International journal of human resource studies, 1(1), 41.

Andrabi, T., Das, J. \& Khwaja, J., A. (2002). Private Schooling in Pakistan: Catering to the Urban Elite? Available at ksghome.harvard.edu/ akhwaja/ papers/Pakschool\%20March29.pdf.

Banks, C.G. \& Murphy, K.R. (1985). Toward narrowing the research-practice gap in performance appraisal. Personnel Psychology, 38, 335-345.

Buller, P. F., \& McEvoy, G. M. (2012). Strategy, human resource management and performance: Sharpening line of sight.Human Resource Management Review, 22, 43-56.

Bohlander, G., Snell, S. \& Sherman, A. 2001. Managing human resources. Ohio: South-Western College Publishing.

Boice, D.F. \& Kleiner, B.H. 1997. Designing effective performance appraisal systems. Work Study 46 (6): 197 201.

Bekele, A. Z, Shigutu, A. D., \& Tensay, A.T. (2014). The Effect of Employees' Perception of Performance Appraisal on Their Work Outcomes. International Journal of Management and Commerce Innovations 2(1), 136-173.

Cleveland, J. N., \& Murphy, K. R. (1992). Analyzing performance appraisal as goal-directed behavior. Research in personnel and human resources management, 10(2), 121-185.

Duncan, W.J. 1983. Management. New York: Random House.

De Cenzo, D.A. \& Robbins, S.P. 1996. Human resource management: concepts \& practices. 4th Ed. New York: John Wiley \& Sons Inc.

Djurdjevic, E. (2013). The effects of social contextual factors on rater motivation and performance ratings. University of Arkansas.

Ministry of Education (1998), National Education Policy 1998-2010, Government of Pakistan, Islamabad.

Decotiis, T., \& Petit, A. (1978). The performance appraisal process: A model and some testable propositions. Academy of Management Review, 3(3), 635-646.

Freinn-von Elverfeldt, A. C. (2005). Performance appraisal: how to improve its effectiveness (Bachelor's thesis, University of Twente).Fink, A. (2003). The survey handbook (Vol. 1). Sage

Farhat saba \& Nsubuga-kyobe, (2014). performance appraisal accuracy: the effects and consequences of rater motivation in performance appraisal context; a case study of pakistan higher education sector. AFBE journal vol.7, no. 2

Fletcher, C. (2001). Performance appraisal and management: The developing research agenda. Journal of Occupational and Organizational Psychology. 74, 473-487.

Gong, Y., Law, K. S., Chang, S., \& Xin, K. R. (2009).Human resources management and firm performance: The differential role of managerial affective and continuance commitment, Journal of Applied Psychology, 94, 263-275.

Grote, R.C. \& Grote, D. 2002. The performance appraisal question and answer book: a survival guide for managers. AMACOM.

Graham, M., Milanowski, A., \& Miller, J. (2012). Measuring and Promoting Inter-Rater Agreement of Teacher and Principal Performance Ratings. Online Submission.

Harris, M. M. (1994). "Rater Motivation in the Performance Appraisal Context: A Theoretical Framework." Journal of Management20(4): 737-756.

Kutschera, I. and Byrd, J. (2005), "Applying the concept of cognitive continuum to leadership training”, Journal of American Academy of Business, Vol. 6 No. 1, pp. 20-5. 
Kisang, f., \& Kirai, d. m. (2016). effects of performance appraisal on employee motivation in commercial banks: a case of equity bank, kenya. strategic journal of business \& change management, 3(4).

Khan, M. A. (2010). Effects of Human Resource Management Practices on Organizational Performance -An Empirical Study of Oil and Gas Industry in Pakistan. European Journal of Economics, Finance and Administrative Sciences, 24, 1450-2275.

Kumar, D. (2005). Performance appraisal: The importance of rater training. Journal of the Kuala Lumpur Royal Malaysia Police College, 4(1), 1-16.

Lee, C. (1985). Increasing performance appraisal effectiveness: Matching task types, appraisal process, and rater training. Academy of management review, 10(2), 322-331.

Longenecker, C., Sims, H., Jr., \& Gioia, D. (1987). Behind the mask: The politics of employee appraisal. The Academy of Management Executive

Longenecker, C. O. (1997). Why managerial performance appraisals are ineffective: causes and lessons. Career Development International, 2(5), 212-218.

Lahuis, D. M., \& Avis, J. M. (2007). Using multilevel randomcoefficient modeling to investigate rater effects in performance ratings. Organizational Research Methods, 10, 97-107.

Mero, N. P., Guidice, R. M., \& Brownlee, A. L. (2007). Accountability in a performance appraisal context: The effect of audience and form of accounting on rater response and behavior. Journal of Management, 33, 223-

Murphy, K. R. (2008). Explaining the weak relationship between job performance and ratings of job performance. Industrial and Organizational Psychology, 1(2), 148-160.

Mohrman, A., \& Lawler, E. (1983). Motivation and performance-appraisal behavior. In F. Landy, S. Zedeck, \& J. Cleveland (Eds.), Performance measurement and Theory (pp. 173-189).

Murphy, K.R. \& Cleveland, J.N. (1991). Performance appraisal: An organizational perspective. Boston, MA: Allyn \& Bacon.

Nayyar, S, \& Raja, N.T. (2012). The Impact of Impression Management Behaviour on Organisational Politics Among Female employees in Organic and Mechanistic System of Pakistan Telecommunication sector, Interdisciplinary Journal of Contemporary Research in Business, 3 (9), 914-924.

Park, S. (2017). Motivating raters through work design: Applying the job characteristics model to the performance appraisal context. Cogent Psychology, 4(1), 1287320.

Rosso, B. D., Dekas, K. H., \& Wrzesniewski, A. (2010). On the meaning of work: A theoretical integration and review. Research in Organizational Behavior, 30, 91-127.

Rasheed M. I, Aslam H. D, Yousaf S. \& Noor A. (2011). A Critical Analysis of Performance Appraisal System for Teachers in Public Sector Universities of Pakistan: A Case Study of the Islamia University of Bahawalpur (IUB). African Journal of Business Management, 5(80), 3297-3301.

Rahman, W. (2012). The Relationship of Attitudinal and Behavioural Outcomes with Employee Development in the Context of Performance Appraisal in Public Universities of Khyber Pakhtunkhwa. PhD Academic), National University of Moderen Langauges, Islamabad.

Roch, S. G., McNall, L. A., \& Caputo, P. M. (2011). Self-judgments of accuracy as indicators of performance evaluation quality: Should we believe them?. Journal of Business and Psychology, 26(1), 41-55. and Management Tomorrow, 2(4), 1-9.

Skylar Powell, K., \& Yalcin, S. (2010). Managerial training effectiveness: A meta-analysis 1952-2002. Personnel Review, 39(2), 227-241.

Schmitt, N. \& Klimoski, R.J. (1991). Research methods in human resources management. Cincinnati, OH: SouthWestern Publishing.

Spence, J. R., \& Keeping, L. M. (2010). The impact of non-performance information on ratings of job performance: A policy-capturing approach. Journal of Organizational Behavior

Tziner, A., Murphy, K. R., \& Cleveland, J. N. (2005). Contextual and rater factors affecting rating behavior. Group \& Organization Management, 30(1), 89-98. 
Tziner, A., Murphy, K., \& Cleveland, J. (2001). Relationships between attitudes toward organizations and performance appraisal systems and rating behavior, International Journal of Selection and Assessment.

Villanova, P., \& Bernardin, H. J. (1989). Impression management in the context of performance appraisal. In R. Giacalone \& P. Rosenfeld (Eds.), New Jersey: Lawrence Erlbaum.

Wang, X. M., Wong, K. F., \& Kwong, J. Y. (2010). The roles of rater goals and ratee performance levels in the distortion of performance ratings. Journal of Applied Psychology, 95, 546-561.

Ying, Z. Y. (2012). The Impact of Performance Management System on Employee performance. Unpublished master thesis. 